\title{
Mitigating water stress on wheat through foliar application of silicon
}

\author{
Rafi Qamar1, Imtiaz Anjum1, Atique-ur-Rehman'2*, Muhammad Ehsan Safdar'1, \\ Hafiz Muhammad Rashad Javeed ${ }^{3}$, Abdul Rehman ${ }^{1}$, Yasir Ramzan ${ }^{4}$ \\ ${ }^{1}$ Department of Agronomy, College of Agriculture, University of Sargodha, Pakistan \\ ${ }^{2}$ Department of Agronomy, Bahauddin Zakariya University, Multan, Pakistan \\ ${ }^{3}$ Department of Environmental Sciences, COMSATS University Islamabad, Vehari Campus, Pakistan \\ ${ }^{4}$ Wheat Research Institute, AARI, Faisalabad, Pakistan
}

\begin{abstract}
Received:
April 26, 2019

Accepted:

October 05, 2019

Published:

February 17, 2020

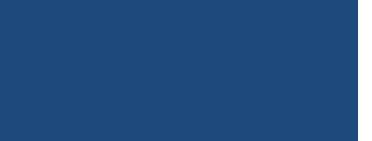

\section{Abstract}

Climate change emerges in different forms such as drought, which is prevalent all over the world, especially in semi-arid and arid regions. Crop production especially wheat (Triticum aestivum L.) yield is affected due to water shortage at critical growth stages in Pakistan. A greenhouse experiment was conducted by using plastic trays to assess the performance of wheat to exogenous silicon $(\mathrm{Si})$ application under water stress which in applied through skipping irrigation at critical stages at College of Agriculture, University of Sargodha, Pakistan. Experiment include irrigation levels $\left(\mathrm{I}_{1:}\right.$ irrigation at crown root stage + booting stage, $\mathrm{I}_{2}$ : irrigation at crown root stage + anthesis stage, $\mathrm{I}_{3}$ : crown root stage + grain development stage, $\mathrm{I}_{4}$ : crown root stage + booting stage + anthesis stage + grain development stage, I $_{5}$ : crown root stage + tillering stage + booting stage + earing stage + milking stage + dough stage) and foliar application of Si viz., $\mathrm{Si}_{0}: 0 \%$ (Control), $\mathrm{Si}_{1}: 0.25 \%, \mathrm{Si}_{2}: 0.50 \%$, and $\mathrm{Si}_{3}: 1 \%$ (w/v). Treatment combination $\mathrm{I}_{1}$ $+\mathrm{Si}_{0}$ significantly reduced yield and yield attributes, net assimilation rate, Si contents in plants, leaf water potential, chlorophyll content, root length and water use efficiency furthermore, increased evapotranspiration efficiency. In contrast, treatment combination $\mathrm{I}_{5}+\mathrm{Si}_{3}$ significantly increased these parameters and reduced evapotranspiration efficiency. Moreover, treatment combinations $\mathrm{I}_{4}+\mathrm{Si}_{3}$ and $\mathrm{I}_{3}+\mathrm{Si}_{3}$ were statistically at par with treatment combination $\mathrm{I}_{5}+\mathrm{Si}_{3}$ which indicating the role of $\mathrm{Si}$ in mitigating negative impact of water shortage and improved these parameters. It is concluded that plant exhibited positive response at irrigation levels $I_{3}$ and $I_{4}$ in combination with foliar-applied $\mathrm{Si}_{3}$ while irrigation level lower than $\mathrm{I}_{3}$ with $\mathrm{Si}_{3}$ was not showed positive improvement in crop productivity.
\end{abstract}

Keywords: Net assimilation rate, Silicon, Water stress, Water use efficiency, Relative water content

\section{How to cite this:}

Qamar R, Anjum I, Rehman AU, Safdar ME, Javeed HMR, Rehman A and Ramzan Y, 2020. Mitigating water stress on wheat through foliar application of silicon. Asian J. Agric. Biol. 8(1):1-10. DOI: 10.35495/ajab.2019.04.174 


\section{Introduction}

Wheat has a leading role in human nutrition and animal feed in the world with the largest harvested area (220.1 million hectares) and the second largest production (749.5 million tons) among cereals. In Pakistan, area under wheat cultivation is 8.7 million hectares which gives 25.4 million tonnes grain production and its contribution in value addition and gross domestic product is 9.1 and $1.7 \%$ respectively (Economic Survey of Pakistan, 2018). The 22\% people of Pakistan are suffering from food shortage due to insufficient wheat production. There are several reasons which restrict the wheat production. However, in recent scenario, climate change has been emerged as a big threat for wheat production in the world (FAO, 2011d). Abnormality in environment like unpredictable and low rainfall especially at maturity and temperature severity at tillering and milking stage resulted in abiotic stress for wheat production. Drought stress along with salinity is two main threats that have reduced about $20 \%$ arable land of the world and especially Pakistan (Munns and Tester, 2008). It has been reported that more than $40 \%$ yield fluctuation of wheat can be attributed to climate change (heat waves and drought) at the global, national, and subnational scales (Zampieri et al., 2017). The worldwide climate change is creating a series of problems that are disturbing the crop production and has also affected the $58 \%$ population which is engaged directly and indirectly related to agriculture (Anonymous, 2012).

Water stress at critical growth stage is the major hindrance for plant growth and development in different climatic conditions (Wang et al., 2014). Wheat is not equally susceptible to water stress during life but some stages like flowering and grain development are severely affected the crop which ultimately causes in yield reduction (Bukhat, 2005; Sinclair, 2011). Water stress at initial critical growth stages like crown root incitation and tillering caused rapid inhibition of roots and shoot which are further leads to stomatal closure resulting in reduction of transpiration rate and $\mathrm{CO}_{2}$ assimilates during photosynthesis (Neumann, 2008). Results from different studies concluded that water stress during flowering stage mainly affected grain number related traits whereas water stress during flowering impacted grain weight. This is consistent with other studies on wheat, where drought during stem extension caused floret and whole spikelet death and drought during grain filling reduced grain size and weight (Oosterhuis and Cartwright, 1983; Dorion et al., 1996; Ji et al., 2010; Pradhan et al., 2012). Water stress at anthesis stage caused reduction in pollination process that ultimately reduced the number of grains (Showemimo and Olarewaju, 2007). Anther development and pollen production are particularly sensitive to abiotic stresses such as heat, leading to severe reductions in crop yield (Hedhly et al., 2009). Drought during grain filling stage influences the partitioning of assimilate and enzymes activation that involved in starch and sucrose production (Sinclair, 2011) and also disturb the nutrients uptake and accumulation in wheat (Hattori et al., 2005). Water stress and high temperature are the exclusive cause that damages the female reproductive organs which leads to losses of fertility and production. Therefore, pollen sterility is not the major determinant of fertility loss under high temperature and water scarcity (Fábián et al., 2019). In wheat, higher temperature and water stress collectively reduced $66 \%$ to $93 \%$ rate of photosynthetic compared with non-stress conditions. Moreover, water stress at intermediate or suboptimal condition increased $24 \%$ water use efficiency (WUE), moreover, high temperature decreased 34\% WUE (Hassan, 2006; Prasad et al., 2011). Sufficient supply of water at anthesis stage enhances the photosynthetic rate and also provides additional period for carbohydrate translocation towards grains which increases the size of grains (Zhang and Oweis, 1999). Crop yield improvement depends upon the water accessibility at following stages i.e. booting, flowering, grain filling and milking stage (Ashraf and Harris, 2004). Water scarcity at later stages causes decrease in grain weight and number (Gupta et al., 2001). Chlorophyll contents are enhanced during vegetative stage under unlimited water supply (Lawson and Blatt, 2014). Water stress during early vegetative growth affects different phenological stages like stem elongation, leaf area, and tillering, maybe by declined $\mathrm{CO}_{2}$ assimilation in the leaf and slow nutrient mobilization to developing tissues due to lower stomatal conductance, transpiration rate and low relative water content (Barnabas et al. 2008; Lipiec et al. 2013).

Silicon ( $\mathrm{Si}$ ) availability to wheat usually low due to its immobility in plants (Hattori et al., 2005) and its accumulation depends on crop species and crop growth stages (Mecfel et al., 2007). Moreover, most of the researcher concluded that Si lower the risk of diseases, improve photosynthetic rate and grain production in cereals under water stress (Shashidhar 
et al., 2008). In vegetative growth, Si seems nonessential while its application in stress condition improves the growth of family Gramineae especially wheat. Plant structural study has exposed that its recommended amount is essential for cell differentiation and development (Liang et al., 2005). Wheat crop is also known as $\mathrm{Si}$ accumulator that is useful for development under abiotic and biotic (diseases and insect) stresses (Liang et al., 2003). However, under favourable condition its functions are minimum (Epstein, 2009; Gong et al., 2005). Application of Si on the foliage of plant under drought develops tolerance in wheat through improving the plant water use efficiency by reduction transpiration from plants surface (Gao et al., 2006). Foliar-applied $\mathrm{Si}$ at tillering and anthesis enhances biomass and grain yield, respectively (Al-aghabary et al., 2005). Exogenous application of $\mathrm{Si}$ at rate of $0.40-0.50 \%$ enhanced about $50 \%$ grain yield under water stress (Harter and Barros, 2011). Plant tissue analysis showed that Si-induced tolerance against water stress through improvement in antioxidant defence system, which diminished the oxidative stress on cell metabolites (Gong and Chen, 2012). In the light of all above studies, it was speculated that exogenous silicon application could reduce the inauspicious effects of water stress on wheat development and physiological traits. Keeping in view the hypothesis, study was planned to investigate the exogenous application of Si on yield and physiological traits of wheat cultivar Punjab-2011 under planned water stress condition.

\section{Material and Methods}

\section{Experimental site and soil}

Role of Si levels on yield and physiological traits of wheat (CV. Punjab-2011) under water stress which imposed by combinations of irrigation scheduling was studied in a greenhouse experiment at College of Agriculture, University of Sargodha, Pakistan, during 2016-17 under semi-arid $\left(32.08^{\circ} \mathrm{N}\right.$ latitude, $72.67^{\circ} \mathrm{E}$ longitude) climate of the Punjab, Pakistan. Soil used was sandy clay loam having physico-chemical characteristics given in Table 1. Greenhouse temperature and humidity was maintained in the range between $26^{\circ} \mathrm{C}$ to $30^{\circ} \mathrm{C}$ and $60 \%$ to $65 \%$ at noontime respectively.
Table-1: Physico-chemical properties of soil used in the study

\begin{tabular}{|c|c|c|c|}
\hline \multirow{2}{*}{$\begin{array}{c}\text { Soil } \\
\text { properties }\end{array}$} & \multicolumn{2}{|c|}{ Values } & \multirow[b]{2}{*}{ Analytical method used } \\
\hline & $\begin{array}{c}\text { Pre- } \\
\text { sowing }\end{array}$ & \begin{tabular}{|c|}
$\begin{array}{c}\text { Post- } \\
\text { harvest }\end{array}$ \\
\end{tabular} & \\
\hline \multicolumn{3}{|l|}{$\begin{array}{l}\text { Mechanical } \\
\text { composition }\end{array}$} & \multirow{5}{*}{$\begin{array}{l}\text { Bouycous hydrometer } \\
\text { Method (Piper, 1966) }\end{array}$} \\
\hline Sand $\left(\mathrm{g} \mathrm{kg}^{-1}\right)$ & $470 \pm 3.1$ & & \\
\hline Silt $\left(\mathrm{g} \mathrm{kg}^{-1}\right)$ & $240 \pm 2.3$ & & \\
\hline Clay $\left(\mathrm{g} \mathrm{kg}^{-1}\right)$ & $290 \pm 1.6$ & & \\
\hline Textural class & \multicolumn{2}{|c|}{ Sandy clay loam } & \\
\hline $\begin{array}{c}\text { Chemical } \\
\text { composition } \\
\text { Saturation } \\
\text { percentage }\end{array}$ & $\begin{array}{l}39.20 \pm \\
1.20\end{array}$ & $\begin{array}{l}41.73 \pm \\
1.15\end{array}$ & $\begin{array}{l}\text { Method 27a, US Salinity } \\
\text { Laboratory Staff, } 1954\end{array}$ \\
\hline $\mathrm{pH}$ & $\begin{array}{c}7.73 \pm \\
0.03\end{array}$ & $\begin{array}{c}7.70 \pm \\
0.05\end{array}$ & $\begin{array}{l}\text { Beckman's Glass } \\
\text { electrode pH meter } \\
\text { (Jackson, 1973) }\end{array}$ \\
\hline $\begin{array}{c}\text { ECe }\left(\mu \mathrm{S} \mathrm{cm}^{-}\right. \\
1)\end{array}$ & $\begin{array}{c}16.39 \pm \\
24.1\end{array}$ & \begin{tabular}{|c|}
$18.79 \pm$ \\
29.78 \\
\end{tabular} & $\begin{array}{c}\text { Conductivity bridge } \\
\text { from } 1: 2: 5 \text { soil water ratio }\end{array}$ \\
\hline $\begin{array}{c}\text { Soil organic } \\
\text { matter }\left(\mathrm{g} \mathrm{kg}^{-}\right. \\
1)\end{array}$ & $\begin{array}{c}8.43 \pm \\
0.68\end{array}$ & $\begin{array}{c}8.59 \pm \\
0.39\end{array}$ & $\begin{array}{l}\text { Walkyey and Black } \\
\text { method (Piper, 1966) }\end{array}$ \\
\hline $\begin{array}{c}\text { Total soil N } \\
\left(\mathrm{mg} \mathrm{kg}^{-1}\right)\end{array}$ & $\begin{array}{c}4.12 \pm \\
9.17\end{array}$ & $\begin{array}{c}4.20 \pm \\
8.34 \\
\end{array}$ & $\begin{array}{c}\text { Modified Kjeldahl } \\
\text { Method (Piper, 1966) }\end{array}$ \\
\hline $\begin{array}{c}\mathrm{NaHCO}_{3} \\
\text { Extractable-P } \\
\left(\mathrm{mg} \mathrm{kg}^{-1} \text { soil }\right)\end{array}$ & $\begin{array}{c}7.59 \pm \\
0.12\end{array}$ & $\begin{array}{c}8.70 \pm \\
0.29\end{array}$ & $\begin{array}{l}\text { Olsen's Method } \\
\text { (Jackson, 1973) }\end{array}$ \\
\hline $\begin{array}{l}\text { Available } \\
\text { potassium } \\
\left(\mathrm{mg} \mathrm{kg}^{-1}\right)\end{array}$ & $\begin{array}{l}267 \pm \\
10.12\end{array}$ & $\begin{array}{l}269 \pm \\
12.10\end{array}$ & $\begin{array}{l}\text { Flame photometric } \\
\quad(\text { Jackson, 1973) }\end{array}$ \\
\hline
\end{tabular}

Values are mean of four replicates followed by $( \pm)$ standard error of means

\section{Crop husbandry}

Seeds of wheat were sown in plastic trays, each of $27.94 \mathrm{~cm}$ width, $54.28 \mathrm{~cm}$ length and $35.86 \mathrm{~cm}$ depth, each plastic tray was filled with $12 \mathrm{~kg}$ soil. The 40 seeds of wheat cultivar --- were sown in each tray. Fertilizer was used as recommended for wheat i.e. 120:100:60 kg ha ${ }^{-1} \mathrm{~N}: \mathrm{P}: \mathrm{K}$ with urea, DAP and $\mathrm{K}_{2} \mathrm{SO}_{4}$, respectively. Nitrogen was used in three splits in which $1 / 3^{\text {rd }}$ along with whole total phosphorus and potassium fertilizers were incorporated in the soil before sowing. Remaining nitrogen dose was top dressed in two equal splits at tillering and anthesis stage. At the completion of germination, 20 seedlings per trays were maintained and irrigated according to water stress treatments.

\section{Experimental treatments and design}

For treatment allocation, completely randomized design (CRD) with factorial arrangement and having four replications was adopted. Study treatments included water stress at different critical growth stages 
viz., $\mathrm{I}_{1:}$ two irrigations at crown root stage + booting stage, $\mathrm{I}_{2}$ : two irrigations, crown root stage + anthesis stage, $\mathrm{I}_{3}$ : two irrigations, at crown root stage + grain development stage, $\mathrm{I}_{4}$ : four irrigations, crown root stage + booting stage + anthesis stage + grain development stage, $\mathrm{I}_{5}$ : six irrigations, crown root stage + tillering stage + booting stage + earing stage + milking stage + dough stage); and foliar application of sodium silicate $\mathrm{Na}_{2} \mathrm{Si}_{3} \mathrm{O}_{7}$ solution with different concentrations viz., $\mathrm{Si}_{0}$ : $0 \%$ (Control, water spray with $0 \mathrm{Si}), \mathrm{Si}_{1}: 0.25 \%$ (10.86 mg/100 mL water), $\mathrm{Si}_{2}: 0.50 \%$ (21.73 mg/100 mL of water), $\mathrm{Si}_{3}: 1 \%$ (43.46 mg/100 $\mathrm{mL}$ of water). For the formulation of $0.25 \%, 0.50 \%$ and $1 \% \mathrm{Si}$ solution, $10.86 \mathrm{mg}, 21.73 \mathrm{mg}$ and $43.46 \mathrm{mg}$ $\mathrm{Na}_{2} \mathrm{Si}_{3} \mathrm{O}_{7}$ was weighted on electrical weighing balance (BL3200HL Japan) and each was dissolved in to 100 $\mathrm{mL}$ of distilled water separately. Exogenous silicon was sprayed at tillering and anthesis stage at the time of sunset to ensure $\mathrm{Si}$ uptake by the leaves in two consecutive days.

\section{Data collection}

At physiological maturity, number of productive tillers was counted from 5 plants than their averages were taken. Height of plants was measured by using meter rod. Grains per spike were counted from 5 plants and then their average was calculated. From each experimental unit a sub-sample of 1000-grain was taken and weighted by an analytical balance (Model Number: HC2204) after oven-drying at $70^{\circ} \mathrm{C}$ for 24 hours in an oven until a constant weight was obtained. At physiological maturity, wheat plants were harvested from each experimental unit, tied up in bundles and tagged accordingly. To determine biological yield of each experimental unit, these bundles were weighed by using bench scale (Model Number: TCS-602). All bundles were threshed separately and grain yield was weighed and converted in $\mathrm{Mg}$ (mega gram) per hectare. Silicon concentration in plants was measured at anthesis and grain filling stage. For, Si analysis, harvested plant samples were washed thoroughly with distilled water. For two days, samples were placed in open air then air dried samples were dried at $70^{\circ} \mathrm{C}$ with the help of air driven oven. After drying, samples were converted into a fine powder through grounding. Digested $0.20 \mathrm{~g}$ plant sample through $50 \% \mathrm{NaOH}$ and $50 \% \mathrm{H}_{2} \mathrm{O}_{2}$ solution than placed the beakers on hot plate at $150^{\circ} \mathrm{C}$ for $2 \mathrm{~h}$ for complete the digestion. Colorimetric molybdenum blue method was used for the estimation of Si from the digested samples (Elliot and Snyder, 1991). Then, take
$50 \mathrm{ml}$ volumetric flask and made a solution having 1 $\mathrm{ml}$ filtrate liquid, $25 \mathrm{ml}$ acetic acid (20\%) and $10 \mathrm{ml}$ of ammonium molybdate. After five minutes add $5 \mathrm{ml}$ tartaric acid (20\%) and $1 \mathrm{ml}$ of reducing solution $(1 \mathrm{~g}$ $\mathrm{Na}_{2} \mathrm{SO}_{3}, 0.5 \mathrm{~g} 1$ amino-2-naphthol-4-sulfonic acid and $30 \mathrm{~g} \mathrm{NaHSO}_{3}$ in $200 \mathrm{ml}$ water) and $20 \%$ citric acid to made the solution up to the volume. Spectrophotometer (Shimadzu, Japan) at $650 \mathrm{~mm}$ was used to check the absorbance. Barrs and Weatherly (1962) method was used for the determination of relative water content. For this purpose, weighted fresh leaflets were imbibing into distilled water for four hours in petri plate. After four hours, turgid weight of leaflets was calculated then dried in an oven at $80^{\circ} \mathrm{C}$ for 48 hours for recording dry weight of leaflets. Following formula was used for calculation of relative water content (RWC):

$R W C(\%)=\frac{\text { Fresh weight }(g)-\text { Dryweight }(g)}{\text { Turgid weight }(g)-\text { Dryweight }(g)} \times 100$

Chlorophyll was measured with chlorophyll meter, model no. (SPAD-502 Plus) between 10:00 AM and 02:00 PM. Each measurement was repeated three times and the average was included for analysis. (Tennant, 1975) method was used for the measurement of root length. For this purpose, randomly selected five plants were dug-out with a sampling tool having $7 \mathrm{~cm}$ sharp cutting tip. Then, soil and other residues were carefully separated from the roots through gentle washing. Root length was noted in centimeters from ground level to the root tips.

Ehdaie and Waines (1994) formulae was used for calculation of water use efficiency and evapotranspiration efficiency (ETE), respectively

$$
\begin{aligned}
& \text { WUE }\left(\mathrm{kg} \mathrm{m}^{-3}\right)=\frac{\text { Grain yield }}{\text { Water used rate }} \\
& \text { ETE }\left(\mathrm{kg} \mathrm{m}^{-3}\right)=\frac{\text { Biological yield }}{\text { Water used rate }}
\end{aligned}
$$

\section{Statistical analysis}

Analysis of variance (ANOVA) techniques was applied on collected data by using the statistical program SAS 9.1 (SAS Institute, 2008) and Duncan's Multiple Range test at $\mathrm{P} \leq 0.05$ was used for comparison of the means (Steel et al., 1997).

\section{Results and Discussion}

Foliar application of Si has significant effect on wheat yield and yield components under irrigation levels 


\section{Rafi Qamar et al.}

(Table 2). Irrigation level $\mathrm{I}_{5}$ showed that full irrigation produced $7 \%$ taller wheat plant than irrigation level $\mathrm{I}_{1}$ (Table 2). Moreover, $\mathrm{Si}_{3}$ in irrigation level $\mathrm{I}_{5}$ produced $15 \%$ taller plant than $\mathrm{Si}_{0}$ at $\mathrm{I}_{1}$ level. Plant height of $\mathrm{I}_{4}$ and $\mathrm{I}_{3}$ were statistically similar with $\mathrm{I}_{5}$ along with $\mathrm{Si}_{3}$. Among Si concentrations, $\mathrm{Si}_{3}$ express $6 \%$ taller plant than $\mathrm{Si}_{0}$ (Table 2). Likewise, $\mathrm{Si}_{3}$ presented $14 \%$ higher productive tillers than $\mathrm{Si}_{0}$ (Table 2) while $\mathrm{I}_{5}$ produced 9\% more productive tillers than water stress $I_{1}$.
Moreover, $\mathrm{Si}_{3}$ along with irrigation level $\mathrm{I}_{5}$ produced $24 \%$ higher productive tillers than $\mathrm{Si}_{0}$ with irrigation level $\mathrm{I}_{1}$ (Table 2). Number of grains per spike in $\mathrm{Si}_{3}$ was $8 \%$ more than that $\mathrm{Si}_{0}$ (Table 2). Irrigation level $\mathrm{I}_{5}$ produced $13 \%$ higher grains per spike than irrigation level $\mathrm{I}_{1}$. Among irrigation $\times$ silicon interactions, $\mathrm{I}_{5}$ and I in combination with $\mathrm{Si}_{3}$ produced $18 \%$ higher grains per spike than those observed with $\mathrm{I}_{1} \times \mathrm{Si}_{0}$ interaction.

Table-2: Irrigation and silicon interaction effect on yield and yield attributes, biological yield, net assimilation rate and silicon contents in plants of semi-arid wheat.

\begin{tabular}{|c|c|c|c|c|c|c|c|c|c|c|}
\hline \multirow{2}{*}{$\begin{array}{l}\text { Irrigation } \\
\text { levels }\end{array}$} & \multirow{2}{*}{$\begin{array}{l}\text { Silicon } \\
\text { Conc. }\end{array}$} & \multirow{2}{*}{$\begin{array}{l}\text { Plant } \\
\text { height } \\
\text { (cm) }\end{array}$} & \multirow{2}{*}{$\begin{array}{l}\text { Tiller } \\
\left(\mathbf{m}^{-2}\right)\end{array}$} & \multirow{2}{*}{$\begin{array}{c}\text { Grains } \\
\text { per } \\
\text { spike }\end{array}$} & \multirow{2}{*}{$\begin{array}{l}\text { 1000-grain } \\
\text { weight (g) }\end{array}$} & \multirow{2}{*}{$\begin{array}{c}\text { Biological } \\
\text { yield } \\
\left(\mathbf{M g ~ h a}^{-1}\right)\end{array}$} & \multirow{2}{*}{$\begin{array}{c}\begin{array}{c}\text { Grain } \\
\text { yield } \\
\left(\mathrm{Mg} \mathrm{ha}^{-1}\right)\end{array} \\
\end{array}$} & \multirow{2}{*}{$\begin{array}{c}\text { NAR } \\
\left(\mathbf{g ~ m}^{-2} \mathbf{d}^{-1}\right) \\
\end{array}$} & \multicolumn{2}{|c|}{ Si contents $\left(\mathrm{mg} \mathrm{g}^{-1}\right)$} \\
\hline & & & & & & & & & Anthesis & Grain \\
\hline & $\mathrm{Si}_{0}(0)$ & $98.3 d^{\Psi}$ & $231 \mathrm{~d}$ & $46.8 \mathrm{~d}$ & $37.7 \mathrm{~d}$ & $8.9 \mathrm{~d}$ & $3.2 \mathrm{~d}$ & $3.6 \mathrm{~d}$ & $4.1 \mathrm{~d}$ & $4.1 \mathrm{~d}$ \\
\hline & $\mathrm{Si}_{1}(0.25 \%)$ & $100.3 \mathrm{c}$ & $243 c$ & $48.1 \mathrm{c}$ & $40.1 \mathrm{c}$ & $12.2 \mathrm{c}$ & $4.3 \mathrm{c}$ & $4.2 \mathrm{c}$ & $5.6 \mathrm{c}$ & $5.2 \mathrm{c}$ \\
\hline & $\mathrm{Si}_{2}(0.50 \%)$ & $102.6 \mathrm{~b}$ & $258 \mathrm{~b}$ & $49.2 b$ & $42.8 \mathrm{~b}$ & $14.1 \mathrm{~b}$ & $5.5 b$ & $4.5 \mathrm{~b}$ & $6.1 \mathrm{~b}$ & $6.1 b$ \\
\hline & $\mathrm{Si}_{3}(1 \%)$ & $105 \mathrm{a}$ & $270 \mathrm{a}$ & $50.6 \mathrm{a}$ & $44 \mathrm{a}$ & $15.8 \mathrm{a}$ & $6.1 \mathrm{a}$ & $5.1 \mathrm{a}$ & $6.8 \mathrm{a}$ & $7.1 \mathrm{a}$ \\
\hline \multicolumn{11}{|c|}{ Irrigation levels $\times$ Foliar application of silicon } \\
\hline \multirow{4}{*}{$\mathrm{I}_{1}$} & $\mathrm{Si}_{0}(0)$ & 92.8 & 213 & 43 & 34.5 & 7.3 & 2.7 & 3.10 & 4.0 & 3.2 \\
\hline & $\mathrm{Si}_{1}(0.25 \%)$ & 96.6 & 225 & 43.1 & 39 & 8.7 & 3.0 & 3.11 & 4.3 & 4.5 \\
\hline & $\mathrm{Si}_{2}(0.50 \%)$ & 98.2 & 245 & 45.1 & 41.2 & 10.1 & 3.2 & 3.10 & 4.7 & 4.7 \\
\hline & $\mathrm{Si}_{3}(1 \%)$ & 98.5 & 254 & 46.2 & 40.6 & 10.8 & 3.9 & 3.5 & 4.5 & 6.0 \\
\hline & Mean & $96.5 C^{\S}$ & $234 \mathrm{C}$ & $44.3 \mathrm{C}$ & $38.8 \mathrm{C}$ & $9.2 \mathrm{C}$ & $3.2 \mathrm{C}$ & $3.2 \mathrm{C}$ & $4.3 \mathrm{C}$ & $4.6 \mathrm{C}$ \\
\hline \multirow[t]{5}{*}{$\mathrm{I}_{2}$} & $\mathrm{Si}_{0}(0)$ & 98.3 & 231 & 45.1 & 38.7 & 8.1 & 3.4 & 3.71 & 4.1 & 3.4 \\
\hline & $\mathrm{Si}_{1}(0.25 \%)$ & 100 & 236 & 46.6 & 39.3 & 11.7 & 3.3 & 3.74 & 5.1 & 5.3 \\
\hline & $\mathrm{Si}_{2}(0.50 \%)$ & 100.5 & 253 & 47.2 & 40.5 & 13.0 & 4.3 & 4.71 & 5.4 & 7.0 \\
\hline & $\mathrm{Si}_{3}(1 \%)$ & 100.6 & 261 & 50.8 & 42.1 & 14.1 & 5.6 & 4.72 & 6.4 & 6.0 \\
\hline & Mean & $99.8 \mathrm{~B}$ & $245 \mathrm{~B}$ & $47.4 \mathrm{~B}$ & $40.1 \mathrm{~B}$ & 11.7B & $4.1 \mathrm{~B}$ & $4.1 \mathrm{~B}$ & $5.2 \mathrm{~B}$ & 5.4B \\
\hline \multirow[t]{5}{*}{$\mathrm{I}_{3}$} & $\mathrm{Si}_{0}(0)$ & 100.3 & 242 & 47.7 & 38.4 & 9.4 & 3.2 & 3.60 & 4.3 & 5.1 \\
\hline & $\mathrm{Si}_{1}(0.25 \%)$ & 101.8 & 248 & 51.9 & 40.2 & 13.9 & 4.7 & 4.90 & 5.6 & 5.6 \\
\hline & $\mathrm{Si}_{2}(0.50 \%)$ & 103.7 & 261 & 51.5 & 43.9 & 14.7 & 6.5 & 5.10 & 7.5 & 5.7 \\
\hline & $\mathrm{Si}_{3}(1 \%)$ & 108.6 & 274 & 50.9 & 46.4 & 17.8 & 6.9 & 5.70 & 7.8 & 7.8 \\
\hline & Mean & $103.6 \mathrm{~A}$ & $256 \mathrm{~A}$ & $50.5 \mathrm{~A}$ & $42.2 \mathrm{~A}$ & $13.9 \mathrm{~A}$ & $5.3 \mathrm{~A}$ & $4.8 \mathrm{~A}$ & $6.3 \mathrm{~A}$ & $6.1 \mathrm{~A}$ \\
\hline \multirow[t]{5}{*}{$\mathrm{I}_{4}$} & $\mathrm{Si}_{0}(0)$ & 100.3 & 227 & 49.3 & 38 & 10.4 & 3.2 & 4.1 & 4.2 & 4.8 \\
\hline & $\mathrm{Si}_{1}(0.25 \%)$ & 101 & 251 & 48.9 & 40.7 & 13.2 & 5.5 & 4.7 & 6.4 & 5.2 \\
\hline & $\mathrm{Si}_{2}(0.50 \%)$ & 105.6 & 272 & 51.2 & 44.8 & 16.5 & 6.6 & 4.8 & 6.1 & 6.6 \\
\hline & $\mathrm{Si}_{3}(1 \%)$ & 108.4 & 279 & 52.8 & 45.5 & 17.6 & 6.7 & 5.8 & 7.8 & 7.8 \\
\hline & Mean & $103.8 \mathrm{~A}$ & $257 \mathrm{~A}$ & $50.5 \mathrm{~A}$ & $42.2 \mathrm{~A}$ & $14.4 \mathrm{~A}$ & $5.5 \mathrm{~A}$ & $4.8 \mathrm{~A}$ & $6.1 \mathrm{~A}$ & $6.1 \mathrm{~A}$ \\
\hline \multirow[t]{5}{*}{$\mathrm{I}_{5}$} & $\mathrm{Si}_{0}(0)$ & 99.8 & 242 & 49 & 38.9 & 9.6 & 3.3 & 3.8 & 4.2 & 4.3 \\
\hline & $\mathrm{Si}_{1}(0.25 \%)$ & 102.2 & 253 & 49.8 & 41.1 & 13.8 & 5.1 & 4.8 & 6.7 & 5.7 \\
\hline & $\mathrm{Si}_{2}(0.50 \%)$ & 105.1 & 265 & 51.3 & 43.6 & 16.5 & 6.9 & 4.9 & 6.8 & 6.7 \\
\hline & $\mathrm{Si}_{3}(1 \%)$ & 108.9 & 281 & 52.6 & 45.8 & 18.7 & 7.2 & 5.8 & 7.9 & 7.9 \\
\hline & Mean & $104 \mathrm{~A}$ & $257 \mathrm{~A}$ & $50.6 \mathrm{~A}$ & $42.3 \mathrm{~A}$ & $14.6 \mathrm{~A}$ & $5.6 \mathrm{~A}$ & $4.8 \mathrm{~A}$ & $6.4 \mathrm{~A}$ & $6.2 \mathrm{~A}$ \\
\hline \multicolumn{2}{|c|}{ DMR P $\leq 0.05(\mathrm{I} \times \mathrm{Si})$} & 5.5 & 17.1 & 3.5 & 3.77 & 3.2 & 1.7 & 0.94 & 1.48 & 2.14 \\
\hline
\end{tabular}

${ }^{\Psi}$ Means separated by lower case letter in each column are not significantly different among foliar application of silicon at $\mathrm{P} \leq 0.05$.

${ }^{\S}$ Means separated by upper case letter in each column are not significantly different among irrigation levels treatments at $\mathrm{P} \leq 0.05$.

ns $=$ Non-significant $;$ NAR $=$ Net assimilation rate 
Regarding 1000-grain weight, I $\mathrm{I}_{5}$ produced $8 \%$ more 1000-grain weight than $I_{1}$ while $I_{4}$ and $I_{3}$ were statistically similar with $\mathrm{I}_{5}$ treatment. In case of $\mathrm{Si}$ concentrations, $\mathrm{Si}_{3}$ produced $14 \%$ higher 1000-grain weight than $\mathrm{Si}_{0}$. IrrigationI 5 in interaction with $1 \% \mathrm{Si}$ produced $25 \%$ more 1000 -grain weight than $\mathrm{Si}_{0}$ with irrigation level $\mathrm{I}_{1}$. Irrigation level $\mathrm{I}_{4}$ and $\mathrm{I}_{3}$ with $\mathrm{Si}_{0}$ showed statistically similar with $\mathrm{I}_{5}$ with $\mathrm{Si}_{3}$ (Table 2). Data showed that $37 \%$ and $43 \%$ higher biological and grain yield in $\mathrm{I}_{5}$ than $\mathrm{I}_{1}$ (Table 2). Irrigation levels $\mathrm{I}_{4}$ and $\mathrm{I}_{3}$ were statistically similar with $\mathrm{I}_{5}$. Exogenous application of $1 \% \mathrm{Si}$ under irrigation level $\mathrm{I}_{5}$ produced $61 \%$ and $63 \%$ higher biological and grain yields, respectively than water stress $\mathrm{I}_{1}$ along with $\mathrm{Si}_{0}$. Among Si concentrations, $\mathrm{Si}_{3}$ produced $44 \%$ and $48 \%$ higher biological and grain yield. Irrigation level $\mathrm{I}_{4}$ and $\mathrm{I}_{3}$ with $\mathrm{Si}_{3}$ were statistically similar with $\mathrm{I}_{5}$ with $\mathrm{Si}_{3}$ (Table 2). Silicon concentration $\mathrm{Si}_{3}$ produced $70 \%$ more net assimilation rate (NAR) than $\mathrm{Si}_{0}$ (Table 2). The trend of $\mathrm{Si}$ application under irrigation level showed that full irrigation along with $1 \%$ Si produced $47 \%$ more NAR than irrigation level $\mathrm{I}_{1}$ along with $\mathrm{Si}_{0}$. Moreover, irrigation levels $\mathrm{I}_{4}$ and $\mathrm{I}_{3}$ with foliar applied $\mathrm{Si} 1 \%$ were statistically similar with $\mathrm{I}_{5}$ in $\mathrm{Si}_{3}$. Likewise, water stress $\mathrm{I}_{5}$ produced $33 \%$ more NAR than water stress $\mathrm{I}_{1}$.

In the present study, foliar applied Si levels at tillering and anthesis stages significantly improved the growth, yield and physiological attributes in wheat when grown under irrigation levels. In water stress, plants enhanced the activities of superoxide dismutase and peroxidase that favoured plant growth and yield (Noman et al., 2015). Water shortage at critical growth stages of wheat significantly declined the crop production through disturbance of nutrients uptake and movement, rate of respiration and photosynthesis (Gupta and Huang, 2014; Cattivelli et al., 2008). Nawaz et al. (2012) described that moisture stress at early growth stage i.e. crown root initiation meaningfully reduced the phonological development due to lack of nutrients uptake which resulted in lower crop production. It is verified by Gupta et al. (2001) that water stress at anthesis and booting stage resulted in lower number of productive tillers due to poor fertilization process. Moreover, productive tillers were positively correlated with grain and biological yield if irrigated at anthesis stage. Consequently, water stress either at reproductive or vegetative stages can affect the physiological maturity by slow growth and development of productive tillers (Dhaka, 2003). It had been proven that availability of irrigation at each critical growth stage resulted in the healthy development of physiological attributes due to timely release of essential amino acids (Zhang et al., 2017). Silicon enhanced the water uptake in plants through improving osmotic potential and activity of aquaporin (Chen et al., 2011). Root hydraulic conductance showed the water uptake capacity of roots (Steudle, 2000; Hattori et al., 2008). It has been verified by the different studies that negative effect of water stress on crops were reduced by the application of $\mathrm{Si}$ (Gong et al., 2005; Hattori et al., 2005). Silicon has remarkable feature in up keeping the relative water contents under water stress (Lux et al., 2002). Iannucci et al. (2002) said that water stress lowered the relative water contents and nutrient uptake in plant body while application of Si on cultivars performed excellent and maintained turgor presser through which plant growth and yield improved.

Data related to $\mathrm{Si}$ concentrations in wheat at anthesis and grain stage as presented in Table 2 revealed that effect of irrigation levels and silicon concentrations imparted significant $\mathrm{p} \leq 0.05$ effect at anthesis and grain formation stage. Among Si treatments, foliar applied $\mathrm{Si}\left(\mathrm{Si}_{3}\right)$ at anthesis and grain formation stages have maximum concentration of $\mathrm{Si} 40 \%$ and $42 \%$, respectively than $\mathrm{Si}_{0}$. Foliar applied $\mathrm{Si} 1 \%$ with irrigation level $\mathrm{I}_{5}$ have $49 \%$ and $60 \%$ higher $\mathrm{Si}$ contents in wheat at anthesis and grain formation stages as compared to $\mathrm{Si}_{0}$ with $\mathrm{I}_{1}$. Irrigation level $\mathrm{I}_{5}$ showed better $(33 \%$ at anthesis and $42 \%$ at grain formation stage) as compared to $\mathrm{I}_{1}$ but $\mathrm{I}_{4}$ and $\mathrm{I}_{3}$ have maximum Si contents in plants and statistically similar with $\mathrm{I}_{5}$. The results also narrated that $\mathrm{Si}$ concentration in plants at anthesis and grain formation stage were significantly $\mathrm{P} \leq 0.05$ increased by the application of $\mathrm{Si}_{3}$ (Table 2). Relative water content (RWC) of leaves as influenced by irrigation levels and foliar applied Siare presented in Table 3. The data on relative water content indicated that $\mathrm{I}_{5}$ with $\mathrm{Si}_{3}$ has $20 \%, 7 \%$ and $12 \%$ higher RWC over $\mathrm{I}_{1}$ with $\mathrm{Si}_{0}$ at 70,95 and 120 DAS respectively. Significantly $\mathrm{p} \leq 0.058 \%, 5 \%$ and $3 \%$ higher RWC were recorded in $\mathrm{Si}_{3}$ at 70, 95 and 120 DAS than $\mathrm{Si}_{0}$. Among irrigation levels, $\mathrm{I}_{5}$ treatment showed $10 \%, 4 \%$ and $4 \%$ higher relative water content than $I_{1}$ at 70,95 and 120 DAS (Table 3). Data of chlorophyll content (SPAD value) indicated that irrigation levels and foliar applied Si (Table 3) had significant $\mathrm{p} \leq 0.05$ effect while their interactive effect was found non-significant at 70, 95 and 120 DAS. 
Rafi Qamar et al.

Table-3: Irrigation and silicon interaction on leaf water and chlorophyll content, root length, water use and evapotranspiration efficiency in plants of semi-arid wheat.

\begin{tabular}{|c|c|c|c|c|c|c|c|c|c|c|}
\hline \multirow{2}{*}{$\begin{array}{c}\text { Irrigatio } \\
\text { n levels }\end{array}$} & \multirow[b]{2}{*}{ Si Conc. } & \multicolumn{3}{|c|}{$\begin{array}{c}\text { Leaf Relative water content } \\
(\%)\end{array}$} & \multicolumn{3}{|c|}{ Chlorophyll content (SPAD) } & \multirow{2}{*}{$\begin{array}{c}\text { Root } \\
\text { length }(\mathrm{cm})\end{array}$} & \multirow{2}{*}{$\begin{array}{l}\text { WUE } \\
\left(\mathbf{k g ~ m}^{-3}\right)\end{array}$} & \multirow{2}{*}{$\begin{array}{c}\text { ETE } \\
\left(\mathrm{kg} \mathrm{m}^{-3}\right)\end{array}$} \\
\hline & & 70 DAS & $\begin{array}{c}95 \\
\text { DAS }\end{array}$ & $\begin{array}{c}120 \\
\text { DAS }\end{array}$ & 70 DAS & 95 DAS & $120 \mathrm{DAS}$ & & & \\
\hline & $\mathrm{Si}_{0}(0)$ & $11.1 \mathrm{c}^{\Psi}$ & $19.8 \mathrm{~d}$ & $29.5 c$ & $28.9 \mathrm{c}$ & $36.7 \mathrm{c}$ & $13.7 \mathrm{~d}$ & $29.6 b$ & $0.82 \mathrm{~d}$ & $2.38 \mathrm{~d}$ \\
\hline & $\mathrm{Si}_{1}(0.25 \%)$ & $11.2 \mathrm{~b}$ & $20.2 c$ & $29.6 c$ & $29.9 \mathrm{bc}$ & $38.2 b$ & $15.8 \mathrm{c}$ & $30.1 \mathrm{~b}$ & $0.89 \mathrm{c}$ & $2.54 \mathrm{c}$ \\
\hline & $\mathrm{Si}_{2}(0.50 \%)$ & $11.6 \mathrm{~b}$ & $20.6 b$ & $29.8 b$ & $30.8 \mathrm{~b}$ & $39.2 b$ & $17.4 \mathrm{~b}$ & $31.0 \mathrm{~b}$ & $1.05 \mathrm{~b}$ & $2.76 b$ \\
\hline & $\mathrm{Si}_{3}(1 \%)$ & $12.1 \mathrm{a}$ & $20.9 \mathrm{a}$ & $30.4 \mathrm{a}$ & $32.5 \mathrm{a}$ & $40.8 \mathrm{a}$ & $19.3 \mathrm{a}$ & $32.2 \mathrm{a}$ & $1.57 \mathrm{a}$ & $3.15 \mathrm{a}$ \\
\hline \multicolumn{11}{|c|}{ Irrigation levels $\times$ Foliar application of silicon } \\
\hline \multirow{5}{*}{$\mathrm{I}_{1}$} & $\mathrm{Si}_{0}(0)$ & 10.3 & 19.8 & 28.0 & 27.2 & 36.5 & 13.2 & 27.3 & 0.55 & 2.37 \\
\hline & $\mathrm{Si}_{1}(0.25 \%)$ & 10.4 & 19.2 & 29.3 & 28.8 & 37.1 & 13.8 & 28.5 & 0.66 & 3.10 \\
\hline & $\mathrm{Si}_{2}(0.50 \%)$ & 10.8 & 20.3 & 29.1 & 30.0 & 37.6 & 16.4 & 29.0 & 0.84 & 3.38 \\
\hline & $\mathrm{Si}_{3}(1 \%)$ & 11.5 & 20.4 & 29.9 & 30.2 & 39.7 & 18.6 & 31.1 & 0.92 & 3.96 \\
\hline & Mean & $10.7 \mathrm{D}^{\S}$ & $19.9 \mathrm{E}$ & $29.1 \mathrm{D}$ & $29.1 \mathrm{~B}$ & $37.7 \mathrm{~B}$ & 15.5 & $29.0 \mathrm{C}$ & $0.74 \mathrm{E}$ & $3.20 \mathrm{~A}$ \\
\hline \multirow{5}{*}{$\mathrm{I}_{2}$} & $\mathrm{Si}_{0}(0)$ & 11.2 & 19.7 & 29.2 & 29.3 & 36.6 & 13.6 & 28.5 & 0.76 & 2.21 \\
\hline & $\mathrm{Si}_{1}(0.25 \%)$ & 11.1 & 20.3 & 29.6 & 30.0 & 37.8 & 14.4 & 30.2 & 0.81 & 3.01 \\
\hline & $\mathrm{Si}_{2}(0.50 \%)$ & 12.0 & 20.2 & 29.6 & 30.4 & 38.4 & 16.3 & 30.6 & 0.91 & 2.03 \\
\hline & $\mathrm{Si}_{3}(1 \%)$ & 11.9 & 20.7 & 30.3 & 31.1 & 40.6 & 19.0 & 31.3 & 1.30 & 3.60 \\
\hline & Mean & $11.5 \mathrm{C}$ & $20.2 \mathrm{D}$ & $29.7 \mathrm{C}$ & $30.2 \mathrm{~A}$ & $38.4 \mathrm{AB}$ & $15.8 \mathrm{AB}$ & $30.2 \mathrm{~B}$ & $0.95 \mathrm{D}$ & $2.71 \mathrm{~B}$ \\
\hline \multirow{5}{*}{$\mathrm{I}_{3}$} & $\mathrm{Si}_{0}(0)$ & 11.0 & 20.2 & 28.5 & 29.4 & 36.9 & 13.4 & 30.7 & 0.86 & 3.30 \\
\hline & $\mathrm{Si}_{1}(0.25 \%)$ & 12.0 & 20.3 & 29.6 & 30.2 & 38.3 & 16.7 & 30.5 & 0.97 & 1.20 \\
\hline & $\mathrm{Si}_{2}(0.50 \%)$ & 11.7 & 20.3 & 29.7 & 30.7 & 40.4 & 18.4 & 31.7 & 1.03 & 3.10 \\
\hline & $\mathrm{Si}_{3}(1 \%)$ & 12.0 & 20.9 & 30.9 & 33.7 & 40.8 & 20.1 & 32.8 & 1.74 & 3.02 \\
\hline & Mean & $11.7 \mathrm{BC}$ & $20.5 \mathrm{C}$ & $29.7 C$ & $31.0 \mathrm{~A}$ & $39.1 \mathrm{~A}$ & $17.2 \mathrm{AB}$ & $31.4 \mathrm{~A}$ & $1.15 \mathrm{C}$ & $2.66 \mathrm{~B}$ \\
\hline \multirow{5}{*}{$\mathrm{I}_{4}$} & $\mathrm{Si}_{0}(0)$ & 11.4 & 19.0 & 29.7 & 29.8 & 36.8 & 14.4 & 30.5 & 0.98 & 2.00 \\
\hline & $\mathrm{Si}_{1}(0.25 \%)$ & 11.0 & 20.2 & 30.2 & 30.4 & 38.8 & 16.3 & 30.6 & 1.03 & 2.01 \\
\hline & $\mathrm{Si}_{2}(0.50 \%)$ & 12.0 & 20.9 & 30.6 & 30.9 & 39.7 & 18.5 & 30.8 & 0.99 & 3.01 \\
\hline & $\mathrm{Si}_{3}(1 \%)$ & 12.4 & 22.0 & 30.7 & 33.7 & 41.0 & 19.3 & 32.8 & 1.89 & 2.90 \\
\hline & Mean & 11.7B & $20.5 \mathrm{~B}$ & $30.3 \mathrm{~B}$ & $31.2 \mathrm{~A}$ & $39.1 \mathrm{~A}$ & $17.1 \mathrm{AB}$ & $31.2 \mathrm{~A}$ & $1.22 \mathrm{~B}$ & $2.48 \mathrm{~B}$ \\
\hline \multirow{5}{*}{$\mathrm{I}_{5}$} & $\mathrm{Si}_{0}(0)$ & 11.8 & 20.3 & 29.0 & 28.6 & 36.7 & 14.1 & 30.8 & 0.96 & 2.01 \\
\hline & $\mathrm{Si}_{1}(0.25 \%)$ & 11.5 & 20.2 & 30.2 & 30.1 & 38.9 & 17.9 & 30.7 & 0.99 & 3.40 \\
\hline & $\mathrm{Si}_{2}(0.50 \%)$ & 11.3 & 20.9 & 30.7 & 31.6 & 39.8 & 17.6 & 32.9 & 1.50 & 2.29 \\
\hline & $\mathrm{Si}_{3}(1 \%)$ & 12.8 & 21.3 & 31.7 & 33.9 & 41.9 & 19.4 & 32.9 & 1.98 & 2.28 \\
\hline & Mean & $11.9 \mathrm{~A}$ & $20.7 \mathrm{~A}$ & $30.4 \mathrm{~A}$ & $31.0 \mathrm{~A}$ & $39.3 \mathrm{~A}$ & $17.3 \mathrm{~A}$ & $31.8 \mathrm{~A}$ & $1.36 \mathrm{~A}$ & $2.50 \mathrm{~B}$ \\
\hline \multicolumn{2}{|c|}{$\begin{array}{c}\mathrm{DMR} \mathrm{P} \leq 0.05 \\
\text { I x Si }\end{array}$} & 0.64 & 0.21 & 0.53 & ns & ns & $\mathrm{ns}$ & Ns & 0.12 & 0.48 \\
\hline
\end{tabular}

${ }^{\Psi}$ Means separated by lower case letter in each column are not significantly different among foliar application of silicon at $\mathrm{P} \leq 0.05$.

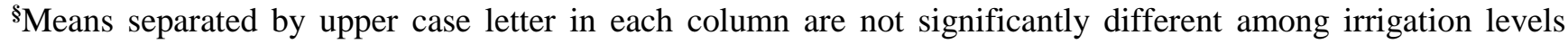
treatments at $\mathrm{P} \leq 0.05$.

ns $=$ Non-significant WUE $=$ Water use efficiency $;$ ETE $=$ Evapotranspiration efficiency

Significantly $\mathrm{p} \leq 0.056 \%, 4 \%$ and $10 \%$ higher chlorophyll contents were recorded in $\mathrm{I}_{5}$ at 70,95 and 120 DAS than $\mathrm{I}_{1}$. Among the foliar applied $\mathrm{Si}, \mathrm{Si}_{3}$ treatment showed $12 \%, 10 \%$ and $29 \%$ higher chlorophyll contents than $\mathrm{Si}_{0}$ at 70, 95 and 120 DAS. There was no significant difference among irrigation levels $I_{3}, I_{4}$ and $I_{5}$ at 70,95 and 120 DAS regrading chlorophyll contents of wheat flag leaf while $\mathrm{I}_{2}$ was statistically similar with $\mathrm{I}_{3}$ and $\mathrm{I}_{4}$ at 95 and 120 DAS. Data showed that significantly $\mathrm{p} \leq 0.05(8 \%)$ higher root length was recorded in $\mathrm{I}_{5}$ than $\mathrm{I}_{1}$ (Table 3 ). Moreover, irrigation levels $\mathrm{I}_{4}$ and $\mathrm{I}_{3}$ were statistically 


\section{Rafi Qamar et al.}

similar with $\mathrm{I}_{5}$ with respect to root length. In case of $\mathrm{Si}$ concentrations, $\mathrm{Si}_{3}$ produced significantly $\mathrm{p} \leq 0.05$ $(8 \%)$ higher root length than control $\mathrm{Si}_{0}$ while $\mathrm{Si}_{0}$ and $\mathrm{Si}_{1}$ were statistically similar with $\mathrm{Si}_{2}$. The interactive effect of irrigation levels and foliar applies $\mathrm{Si}$ were found non-significant (Table 3). Significantly (46\%) higher (WUE) was recorded in water stress $I_{5}$ than $I_{1}$ (Table 3). Application of $\mathrm{Si}_{3}$ under irrigation level $\mathrm{I}_{5}$ showed $72 \%$ more WUE than under $\mathrm{I}_{1}$ with $\mathrm{Si}_{0}$. Moreover, $\mathrm{Si}_{3}$ showed $48 \%$ more WUE than $\mathrm{Si}_{0}$. Regarding evapotranspiration efficiency (ETE) of wheat, irrigation level $\mathrm{I}_{5}$ along with $\mathrm{Si}_{3}$ showed $42 \%$ lower ETE than $\mathrm{I}_{1}$ along with $\mathrm{Si}_{0}$ (Table 3 ). Water stress $\mathrm{I}_{5}$ showed $22 \%$ lower ETE than $\mathrm{I}_{1}$ while $\mathrm{I}_{5}, \mathrm{I}_{4}, \mathrm{I}_{3}$ and $\mathrm{I}_{2}$ were statistically similar with each other. Foliar applied $\mathrm{Si}_{3}$ gave 24\% lower ETE than $\mathrm{Si}_{0}$.

Above findings showed the significant reduction in chlorophyll content due to stress levels. Chlorophyll content is a significant indicator which showed the plant productivity in terms of biomass production (Wang and Huang, 2004). Roy Deluca (2013) stated that wheat under water stress along with Si application significantly affected photosynthetic rate and root length compared than control. Wheat crop up to $60 \%$ and other crops up to $20 \%$ were less affected by drought with application of Si that increased the root surface area, volume, activity and total length due to which more water absorbed from soil which improved plant growth (Chen et al., 2011). Studies revealed that $\mathrm{Si}$ caused significant enhancement in water use efficiency through stimulating enzymatic, nonenzymatic and anti-oxidative defense systems (Liang et al., 2003; Hattori et al., 2005). Evapotranspiration demands to wheat crop have been increased as a result of evaporation due to minimum and sparse plant population and more area faced to sunlight which resulted in reduction of grain yield and water use efficiency. Optimum level of $\mathrm{Si}$ decreased the conductance and transpiration rate for leaf that was associated with plant growth under drought condition but no significant effect was recorded on conductance and transpiration rate from cuticle in plant due to $\mathrm{Si}$ supply by causing the Si polymers formation on root (Gao et al., 2006).

\section{Conclusion}

It can be concluded that Si application significantly increased biomass and grain yield of wheat cultivar under different irrigation levels, which was found to be associated with $\mathrm{Si}$-induced increased relative water content, chlorophyll content, root length and water use efficiency. Therefore, application of Si is an effective way of increasing production of wheat in arid or semiarid areas.

\section{Acknowledgement}

The authors of this manuscript would like to thank the College of Agriculture, University of Sargodha, Sargodha, Pakistan for their financial support for this study.

Disclaimer: None.

Conflict of Interest: None.

Source of Funding: This study was funded by college of Agriculture, University of Sargodha, Sargodha, Pakistan.

\section{References}

Al-aghabary K, Zhu Z and Shi Q, 2005. Influence of silicon supply on chlorophyll content, chlorophyll fluorescence, and antioxidative enzyme activities in tomato plants under salt stress. J. Plant Nutr. 27: 2101-2115.

Anonymous (Economic Survey of Himachal Pradesh), 2012. Shimla: Economics and Statistics Department.Available:http://himachal.nic.in/econ omics/pdfs/econSurveyEng2012_A1b.pdf.

Accessed 2013 January 24.

Ashraf MPJC and Harris PJC, 2004. Potential biochemical indicators of salinity tolerance in plants. Plant Sci. 166: 3-16.

Barnabas B, Jäger K and Fehér A, 2008. The effect of drought and heat stress on reproductive processes in cereals. Plant Cell Environ. 31: 11-38.

Barrs HD and Weatherley PE, 1962. A re-examination of the relative turgidity technique for estimating water deficits in leaves. Aust. J. Biol. Sci. 15: 413428.

Bukhat NM, 2005. Studies in yield and yield associated traits of wheat (Triticum aestivum L.) genotypes under drought conditions. M.S. Thesis, Department of Agronomy, Sindh Agriculture University of Tandojam, Pakistan.

Cattivelli L, Rizza F, Badeck FW, Mazzucotelli E, Mastrangelo AM, Francia E and Stanca AM, 2008. Drought tolerance improvement in crop plants: an 
integrated view from breeding to genomics. Field Crops Res. 105: 1-14.

Chen W, Yao X, Cai K and Chen J, 2011. Silicon alleviates drought stress of rice plants by improving plant water status, photosynthesis and mineral nutrient absorption. Biol. Trace Elem. Res. 142: 67-76.

Dhaka AK, 2003. Biomass partitioning of wheat genotypes as influenced by different sowing times and irrigation conditions, Doctoral dissertation, Chaudhary Charan Singh Agricultural University of Haryana, Hisar, India.

Dorion S, Lalonde S and Saini HS, 1996. Induction of male sterility in wheat by meiotic-stage water deficit is preceded by a decline in invertase activity and changes in carbohydrate metabolism in anthers. Plant Physiol. 111: 137-145.

Economic Survey of Pakistan, 2018. Ministry of Finance. Government of Pakistan. 22 pp.

Ehdaie B and Waines JG, 1994. Growth and transpiration efficiency of near-isogenic lines for height in a spring wheat. Crop Sci. 34: 1443-1451.

Epstein E, 2009. Silicon: its manifold roles in plants. Ann. Appl. Biol. 155: 155-160.

Fábián A, Sáfrán E, Szabó-Eitel G, Barnabás B and Jäger K, 2019. Stigma Functionality and Fertility are Reduced by Heat and Drought Co-stress in Wheat. Front. Plant Sci. 10: 244-244.

FAO, 2011d. Climate change, water and food security. FAO Water Reports 36, Rome, FAO.

Gao X, Zou C, Wang L and Zhang F, 2006. Silicon decreases transpiration rate and conductance from stomata of maize plants. J. Plant Nutr. 29:16371647.

Gong $\mathrm{H}$ and Chen K, 2012. The regulatory role of silicon on water relations, photosynthetic gas exchange, and carboxylation activities of wheat leaves in field drought conditions. Acta Physiol. Planta. 34: 1589-1594.

Gong H, Zhu X, Chen K, Wang S and Zhang C, 2005. Silicon alleviates oxidative damage of wheat plants in pots under drought. Plant Sci. 169:313-321.

Gupta B and Huang B, 2014. Mechanism of salinity tolerance in plants: physiological, biochemical, and molecular characterization. Int. J. Genom. http://dx.doi.org/10.1155/2014/701596.

Gupta N K, Gupta S and Kumar A, 2001. Effect of water stress on physiological attributes and their relationship with growth and yield of wheat cultivars at different stages. J. Agron. Crop Sci. 186: 55-62.
Harter FS and Barros ACSA, 2011. Calcium and silicon on production and quality of soybean seeds. Rev. Bras. Semen. 33: 54-60.

Hassan IA, 2006. Effects of water stress and high temperature on gas exchange and chlorophyll fluorescence in Triticum aestivum L. Photosynthetica. 44: 312-315.

Hattori T, Sonobe K, Araki H, Inanaga S, An P and Morita S, 2008. Silicon application by sorghum through the alleviation of stress-induced increase in hydraulic resistance. J. Plant Nutr. 31: 1482-1495.

Hattori T, Inanaga S, Araki H, An P, Morita S, Luxová $M$ and Lux A, 2005. Application of silicon enhanced drought tolerance in Sorghum bicolor. Physiol. Plant. 123: 459-466.

Hedhly A, Hormaza JI and Herrero M, 2009. Global warming and sexual plant reproduction. Trends Plant Sci. 14: 30-36.

Iannucci A, Russo M, Arena L, Di Fonzo N and Martiniello P, 2002. Water deficit effects on osmotic adjustment and solute accumulation in leaves of annual clovers. Eur. J. Agron. 16: 111122.

Jackson ML, 1973. Methods of chemical analysis. Prentice Hall of India. Pvt. Ltd. New Delhi, 498.

Ji X, Shiran B, Wan J, Lewis DC, Jenkins CL and Condon AG, 2010. Importance of pre-anthesis anther sink strength for maintenance of grain number during reproductive stage water stress in wheat. Plant Cell Environ. 33: 926-942.

Lawson T and Blatt MR, 2014. Stomatal size, speed, and responsiveness impact on photosynthesis and water use efficiency. Plant Physiol. 164: 15561570.

Liang Y, Chen QIN, Liu Q, Zhang W and Ding R, 2003. Exogenous silicon (Si) increases antioxidant enzyme activity and reduces lipid peroxidation in roots of salt-stressed barley (Hordeum vulgare L.). J. Plant Physiol. 160: 1157-1164.

Liang Y, Zhang W, Chen Q and Ding R, 2005. Effects of silicon on H+-ATPase and H+-PPase activity, fatty acid composition and fluidity of tonoplast vesicles from roots of salt-stressed barley (Hordeum vulgare L.). Environ. Exp. Bot. 53: 2937.

Lipiec J, Doussan C, Nosalewicz A and Kondracka K, 2013. Effect of drought and heat stresses on plant growth and yield: A review. Int. Agrophys. 27: 463-477.

Lux A, Luxová M, Hattori T, Inanaga S and Sugimoto Y, 2002. Silicification in sorghum (Sorghum 
bicolor) cultivars with different drought tolerance. Physiol. Plant. 115: 87-92.

Mecfel J, Hinke S, Goedel WA, Marx G, Fehlhaber R, Bäucker E and Wienhaus O, 2007. Effect of silicon fertilizers on silicon accumulation in wheat. J. Plant Nutr. Soil Sci. 170: 769-772.

Munns R and Tester M, 2008. Mechanisms of salinity tolerance. Ann. Rev. Plant Biol. 59: 651-681.

Nawaz F, Ahmad R, Waraich EA, Naeem MS and Shabbir RN, 2012. Nutrient uptake, physiological responses, and yield attributes of wheat (Triticum aestivum L.) exposed to early and late drought stress. J. Plant Nutr. 35: 961-974.

Noman A, Ali S, Naheed F, Ali Q, Farid M, Rizwan $M$ and Irshad MK, 2015. Foliar application of ascorbate enhances the physiological and biochemical attributes of maize (Zea mays L.) cultivars under drought stress. Arch. Agron. Soil Sci. 61: 1659-1672.

Neumann PM, 2008. Coping mechanisms for crop plants in drought-prone environments. Ann. Bot. 101: 901-907.

Oosterhuis DM and Cartwright PM, 1983. Spike differentiation and floret survival in semi dwarf spring wheat as affected by water stress and photoperiod. Crop Sci. 23: 711-777.

Piper CS, 1966. Soil and plant analysis; A laboratory manual of methods for the examination of soils and the determination of the inorganic constituents of plants. Hans Publishers; Bombay.

Pradhan GP, Prasad PV, Fritz AK, Kirkham MB and Gill BS, 2012. Effects of drought and high temperature stress on synthetic hexaploid wheat. Funct. Plant Biol. 39: 190-198.

Prasad PVV, Pisipati SR, Momčilović I and Ristic Z, 2011. Independent and combined effects of high temperature and drought stress during grain filling on plant yield and chloroplast EF-Tu expression in spring wheat. J. Agron. Crop Sci. 197: 430-441.

Roy Deluca S, 2013. Effects of excess root applied silicon on Triticum aestivum and Zea mays under Aphis gossypii and Schistocerca gregaria herbivory and water-stressed conditions. Doctoral dissertation, University of Sussex, UK.

SAS Institute, 2008. SAS/STAT 9.1 User's Guide the Regular Procedure, (Book Excerpt). SAS Institute, Cary, NC, USA.

Shashidhar HE, Chandrashekhar N, Narayanaswamy C, Mehendra AC and Prakash NB, 2008, October. Calcium silicate as silicon source and its interaction with nitrogen in aerobic rice. Silicon in Agriculture: $4^{\text {th }}$ International Conference. pp. 2631.

Showemimo FA and Olarewaju JD, 2007. Drought tolerance indices in sweet pepper (Capsicum annuиm L.). Int. J. Plant Breed Genet. 1: 29-33.

Sinclair R, 2011. Challenges in breeding for yield increase for drought. Trends Plant Sci. 6: 289-293.

Steel RGD, Torrie JH and Dicky DA, 1997. Principles and Procedures of Statistics a biometric approach. Third edition. McGraw-Hill Publishing Company, New York, USA. pp. 178-198.

Steudle E, 2000. Water uptake by roots: effects of water deficit. J. Exp. Bot. 51: 1531-1542.

Tennant D, 1975. A test of a modified line intersects method of estimating root length. J. Ecol. 63(3): 995-1001.

Wang L, Chen W and Zhou W, 2014. Assessment of future drought in Southwest China based on CMIP5 multimodel projections. Adv. Atmos. Sci. 31: 1035-1050.

Wang Z and Huang B, 2004. Physiological recovery of Kentucky bluegrass from simultaneous drought and heat stress. Crop Sci. 44: 1729-1736.

Zampieri M, Ceglar A, Dentener F and Toreti A, 2017. Wheat yield loss attributable to heat waves, drought and water excess at the global, national and subnational scales. Environ. Res. Lett. 12: 064008.

Zhang H and Oweis T, 1999. Water-yield relations and optimal irrigation scheduling of wheat in the Mediterranean region. Agric. Water Manage. 38: 195-211.

Zhang P, Ma G, Wang C, Lu H, Li S, Xie Y and Guo $\mathrm{T}$, 2017. Effect of irrigation and nitrogen application on grain amino acid composition and protein quality in winter wheat. PloS One. 12:017849.

\section{Contribution of Authors}

Qamar R: Supervised the experiment and approved the manuscript

Anjum I: Performed experiment

Rehman AU: Statistical analysis and manuscript write up

Safdar ME: Provided experimental inputs Javeed HMR: Manuscript write up

Rehman A: Designed experimental layout

Ramzan Y: Helped in chemical analysis 